\title{
A curious episode in the history of appellate jurisdiction: the Supreme Court of Judicature Act 1873 and ecclesiastical appeals
}

\author{
by Charlotte Smith
}

\section{INTRODUCTION}

$\mathrm{S}$ ince the reforms to matrimonial and testamentary jurisdiction stripped the ecclesiastical courts of almost all of their business it is perhaps understandable that few lawyers ever turn their attention to ecclesiastical jurisdiction. The jurisdiction left to the ecclesiastical courts generated only a small number of suits and was concerned purely with the buildings and fabric of churches and the conduct of church officers. The resulting decline in the legal significance of the ecclesiastical courts and their personnel happened at a time when the Church of England was beginning to lose its dominant position in the life of the nation and the machinery of the state.

Despite this, there are several compelling reasons why lawyers, especially those with an interest in legal history, should look to the history of the ecclesiastical courts after 1860. Firstly, in an era characterised by rapid change and turmoil in the life of the Church of England, that jurisdiction which remained to the ecclesiastical courts heard suits which generated both huge public interest and intense controversy; and which had profound consequences for the Church as an institution and as a religious community.

Secondly, the high profile of ecclesiastical suits, and the controversy which surrounded them, prompted many attempts to reform ecclesiastical jurisdiction. These reform initiatives were themselves the subject of fierce debate. Further, one of the main fora in which they were agitated was Parliament, and the primary mechanism for reform was legislation. Given this, ecclesiastical court reform could, and did, both interact with, and influence, the secular law reform agenda. This article examines one instance of this: the interaction of attempts to reform ecclesiastical appellate jurisdiction and the proposals put forward by Lord Selborne in the Supreme Court of Judicature Bill 1873.

\section{A BRIEF HISTORY OF ECCLESIASTICAL APPEALS $1830-73$}

The history of nineteenth century attempts to reform ecclesiastical appeals began with the efforts of Henry Brougham, and with the special report of the first Royal Commission on Ecclesiastical Courts in which he had a pivotal role. The Royal Commission was scathing in its assessment of the fitness of the existing court of final ecclesiastical appeal, the High Court of Delegates. Noting the lack of expertise of its judges, its ad hoc composition, the numerous opportunities for appeal which led to a lack of finality of process, and the level of expense and delay which litigants incurred as a result, the Commission recommended wholesale reform. Brougham's solution was to transfer final appellate jurisdiction in ecclesiastical suits to the Privy Council, under the Privy Council Appeals Act 1832, and then to the newly formulated Judicial Committee of the Privy Council, under the Judicial Committee Act 1833.

No special provision was made in the 1833 Act for the staffing of the Judicial Committee when it heard ecclesiastical appeals. As such, there was no legal requirement that one or more bishops should be upon the panel or present at these hearings. In this respect the Judicial Committee contrasted strongly with the mixed character of the High Court of Delegates, which had been 
composed of common law and Chancery judges sitting together with civilians and bishops. However, the 1833 Act did empower the President of the Council to call nonjudicial members, including the Archbishops and senior bishops, to attend hearings of the Judicial Committee. This power was used to ensure that at least one bishop attended ecclesiastical hearings, and a convention was quickly established to this effect.

Despite consistent obedience to the convention certain sections of the Church, particularly those in the High Church tradition, were dissatisfied with the composition of the Judicial Committee. In particular, they deprecated the absence of a legal guarantee that one or more bishops would form part of the panel. These concerns were at least partially addressed by the Church Discipline Act 1840, which provided that at least one bishop should sit as a judge in any appeal brought under the Act. Yet many continued to be dissatisfied, not least because in ecclesiastical suits brought by procedures other than that detailed in the 1840 Act there remained no legal guarantee that one of the judges would be a bishop.

In the face of mounting concerns about the weakness of the Judicial Committee's ecclesiastical component the High Church Bishop of London, Blomfield, introduced a string of Bills into the House of Lords in the late 1840s and 1850. None of these Bills, which would have required the Judicial Committee to submit all doctrinal cases to a panel of bishops for their opinion, passed first reading in the House of Lords. There was strong opposition to what were seen as attempts to subjugate the authority of the court to a panel of non-lawyers, many of whom held strong opinions on the matters at issue. In spite of this the Lower House of the Convocation of Canterbury, which was dominated by High Church clergy, revived these proposals in 1865. Once again the proposal met with failure in the face of fierce opposition.

The High Church theme of seeking a stronger episcopal or theological element in the composition of the final court of ecclesiastical appeal was perpetuated in the last reform proposals advanced before the debates provoked by the Judicature Bill in 1873. These proposals, put forward by a committee of the first Pan-Anglican Conference of home and colonial bishops, argued that ecclesiastical appeals should be heard by a court staffed by bishops and Archbishops. They further recommended that the episcopal and archiepiscopal judges should be assisted by six assessors, three lawyers and three theologians. No further action resulted from these proposals.

An examination of ecclesiastical appeals between 1830 and 1873 thus makes three things clear. Firstly, the composition of the Judicial Committee varied according to the procedure or jurisdiction under which the suit was brought. Church Discipline Act appeals would always be heard by a panel including at least one bishop, but other appeals might not be. Secondly, attempts to reform ecclesiastical appeals generally formed part of a response to episodes of ecclesiastical controversy. Those of the 1830s, together with the Church Discipline Act 1840, were prompted by high profile difficulties in enforcing standards of clerical conduct and ministry. In the $1850 \mathrm{~s}$ and $1860 \mathrm{~s}$ attention shifted to appeals in doctrinal suits in consequence of several highly publicised prosecutions of doctrinal heterodoxy. Finally, it can be seen that those proposals for reform which were initiated by the High Church tended both to increase the ecclesiastical or episcopal element in the appeal court, and to impose limits upon the role of legally trained judges in doctrinal cases.

\section{THE ECCLESIASTICAL APPEALS QUESTION AND THE SUPREME COURT OF JUDICATURE BILL 1873}

In the years immediately after 1867 there was a lull in attempts to reform ecclesiastical appeals. There was, it appeared, little prospect of securing either a change to the composition of the Judicial Committee, or a transfer of ecclesiastical jurisdiction to a new court. Lord Selborne's speech on introducing his Judicature Bill to the House of Lords in 1873 gave no reason to suppose that this would change. He explicitly stated that the Bill would in no way touch ecclesiastical appeals. Yet the debates which followed witnessed one of the most significant episodes in the history of later nineteenth century attempts to reform ecclesiastical jurisdiction, and demonstrated the potential impact upon secular court reform of questions relating to the ecclesiastical courts.

It was the actions of the prominent High Church and Conservative peer Lord Salisbury which first indicated that the detractors of the Judicial Committee would use the Judicature Bill to secure change. Salisbury denounced the failure to address the question of ecclesiastical appeals. He proposed an amendment to the Bill which would have transferred ecclesiastical appeals to the new (secular) court of appeal. His amendment found some favour among members of the House but was defeated following objections by Archbishop Tait, who disliked the lack of ecclesiastical expertise in the proposed court, and by Lord Chancellor Selborne and Lord Cairns, who deemed the amendment inexpedient.

A disgruntled but resigned Lord Salisbury accepted the defeat of his amendment and the Bill proceeded to the House of Commons without making any changes to ecclesiastical appeals. Here, however, his amendment was revived. This time it met with success. In the House of Commons the proposal to transfer ecclesiastical appeals to the new Court of Appeal came, not from a noted High Churchman, but from the moderate Anglican and Conservative MP Gathorne Hardy.

Hardy's amendment was put forward in a sparsely populated House during the committee stage of the Bill. Despite the evident surprise of the Prime Minister, William 
Gladstone, who commented on the very unusual degree of agreement between MPs of all political and religious persuasions, it met with almost universal approval. Given this, and given the acknowledged problems with the existing jurisdiction of the Judicial Committee, Gladstone gave his support to the amendment. It passed without division and the Bill was returned to the House of Lords in a form which divested the Judicial Committee of its ecclesiastical jurisdiction.

Upon the Bill's return to the House of Lords it was plain that Lord Selborne, who himself had no objection to the transfer of jurisdiction, felt unable to withstand the weight of the support behind Hardy's amendment. Further, he was convinced that the proposed change would be made at some point in the future, even if it was not made in the present Bill. He was himself convinced that the question of ecclesiastical appeals would have to be addressed sooner or later, and that another opportunity to secure reform might not present itself in such a favourable form.

Though Selborne seemed happy with Hardy's amendment, and though it secured broad support in the House of Lords, he was forced to contend with the opposition of many of the bishops, including the Archbishops. His solution was to propose an amendment which conferred jurisdiction in ecclesiastical appeals upon the new Court of Appeal, but which provided that when that court heard such appeals it would be assisted by seven episcopal assessors. This, he hoped, would provide the appellate court with sufficient ecclesiastical expertise to appease the Archbishops, but would do so without compromising the legal character of the court, which was a central concern of those who supported the transfer of jurisdiction. Selborne's amendment, though it failed to appease the bishops, was grudgingly accepted by both Houses.

\section{THE SUPREME COURT OF JUDICATURE ACT 1873 AND CONFUSION SURROUNDING ECCLESIASTICAL APPEALS}

The Judicature Act provided that the transfer of ecclesiastical appeals to the new Court of Appeal would be secured by Order in Council and undertaken at the discretion of the Crown. Upon such a transfer being made the Act determined that the Court of Appeal would be assisted by seven episcopal assessors when it heard ecclesiastical appeals. It also repealed section 16 of the Church Discipline Act 1840. As such it secured one uniform final court of appeal in all ecclesiastical cases, and ensured that bishops would always be present at its hearings, but only as assessors and never as judges. Henceforth the court of final ecclesiastical appeal was to be a purely legal one, but one which could have reference to ecclesiastical assessors.

The Judicature Act 1873 did not, however, settle the matter of ecclesiastical appeals, since reforms to ecclesiastical jurisdiction became entangled in the continued wrangles over secular appeals. The 1873 Act left unresolved the question of secular appellate jurisdiction in general, and the jurisdiction of the House of Lords in particular. In consequence, its arrangements in respect of ecclesiastical appeals were left in a state of limbo until the passage of Lord Cairns' Appellate Jurisdiction Act in 1876 resolved matters. This Act stipulated that the Judicial Committee of the Privy Council would retain its jurisdiction over ecclesiastical appeals, but adopted the 1873 provisions in relation to the composition of the court. The brief life of the Court of Appeal as an ecclesiastical court was ended before it began.

\section{REFLECTIONS UPON ECCLESIASTICAL COURT REFORM IN PARLIAMENT}

\section{The perils and consequences of the parliamentary process}

The story of ecclesiastical appeals which has been elaborated is a long and complicated one, but it is one which has much to teach us. In the first place it demonstrates both the shifting treatment of Church questions in Parliament, and the unpredictability and potential for havoc created by the Church of England's reliance upon Parliament in key areas. In 1873, after all, ecclesiastical jurisdiction was transferred from the Judicial Committee to the new Court of Appeal on the basis of an amendment proposed by a private member in the House of Commons. Parliament made this change in the teeth of vehement opposition from the Archbishops and senior bishops.

The manner in which the reform of ecclesiastical jurisdiction was secured did not pass without comment. Some parliamentarians complained about the failure to consult the bishops on the proposed change, and about the introduction of such profound reforms by a private member rather than by the government. Many of the same parliamentarians were also horrified that such weighty ecclesiastical matters were dealt with in a secular Bill, rather than by one dealing solely with ecclesiastical matters.

None of these concerns, however, were sufficient to halt the transfer of jurisdiction in 1873. The old conventions regulating the treatment of Church questions in Parliament had clearly changed. It was no longer expected that Church legislation should always take the form of government Bills. It was noted that it had been for some years the practice for reforms to be promoted by private members, particularly when they concerned the ecclesiastical courts. Pragmatists also recognised the increasing difficulty faced by the Church in securing parliamentary time, and the unwillingness of the government to put its weight behind ecclesiastical reforms at a time when the Church was increasingly divided over the questions at issue. They seized the opportunity offered 
by the Judicature Bill in 1873 both because they were convinced that things would have to change, and because they believed that no better opportunity for reform would present itself.

The treatment which ecclesiastical appeals received at the hands of Parliament between 1873 and 1875 was as problematic as the manner in which the reforms were introduced. That treatment starkly illustrated the perils and pitfalls of the parliamentary process. In the first place, only a miniscule amount of parliamentary time was devoted to ecclesiastical appeals within the debates about judicature reform. Further, Hardy's amendment, transferring ecclesiastical jurisdiction to the Court of Appeal, was made upon only twenty-four hours notice. It was passed without division by a sparsely populated House of Commons after only scant debate. Equally worrying was the fact that, though there was a general assumption that the court would be staffed by lawyers, there was almost no discussion of the staffing of the Court of Appeal in ecclesiastical cases.

The treatment meted out to ecclesiastical appeals by the House of Lords was no better, and provoked Archbishop Tait into rebuking the House for treating matters of profound importance to the Church in an "off-hand" manner. Lord Selborne's proposal that the Court of Appeal should be assisted by a panel of episcopal assessors was agreed after only a very short debate. Similarly, that part of the Appellate Jurisdiction Act 1876 which confirmed the ecclesiastical jurisdiction of the Judicial Committee, and which determined its composition in line with the proposals of 1873 , was barely noted.

\section{The relationship between secular and ecclesiastical court reform}

While it was evident that the parliamentary process created problems with respect to reform, it was equally obvious that the parliamentary context exercised a profound influence over the shape which reforms took. The most obvious consequence of this was the close relationship between secular and ecclesiastical court reform.

Within the context of the Judicature Act 1873 and the Appellate Jurisdiction Act 1876 the relationship between secular and ecclesiastical court reform was patent. Reforms to both jurisdictions were undertaken in the same piece of legislation. The relationship was, however, echoed in less obvious ways in the content of the ecclesiastical provisions of the Acts of 1873 and 1876, and in the provisions of a separate attempt to reform ecclesiastical jurisdiction by the Public Worship Regulation Act 1874. Thus the provision for episcopal assessors in the court of final ecclesiastical appeal echoed both arrangements in the Judicial Committee Act 1833, which provided for the attendance of two retired colonial judges at colonial appeals in the Judicial Committee, and arrangements enacted under the 1873 Act to ensure that the Court of Appeal had access to professional expertise when adjudicating appeals on certain matters. Similarly, the Public Worship Regulation Act echoed the secular reforms of 1873 by unifying the ecclesiastical courts (at least for the purpose of causes brought under that Act) into a single court of first instance with a single appeal to one appeal court.

The fact that ecclesiastical jurisdiction was reformed by Parliament, and within the context of reforms to the secular legal system, shaped the arguments advanced for ecclesiastical reform. In 1873 two of the most frequently cited reasons for supporting the transfer of ecclesiastical appeals to the new Court of Appeal were that the Bill would weaken the Judicial Committee, (particularly as it seemed likely at one point that that court would lose its colonial jurisdiction), and that the Judicial Committee was too expensive to maintain for the small number of cases it actually heard. The arguments advanced generally reflected the secular law reform agenda, speaking of the need for legal expertise, a regularly constituted and adequately staffed court, procedural efficiency, and a minimisation of expense.

The absence of "church" arguments about ecclesiastical appeals was a notable feature of the parliamentary debates between 1873 and 1876. Arguments about the spiritual authority of the ecclesiastical courts, which formed the basis of almost all debates about ecclesiastical jurisdiction at that time, were almost entirely absent. This was despite the fact that many of those who spoke in Parliament had published letters and pamphlets which advanced arguments for reform based almost entirely upon different attitudes towards the spiritual authority of the ecclesiastical courts. Within Parliament it became evident that they preferred to advance arguments which echoed assumptions and considerations which were applicable to all courts, whether secular or ecclesiastical. This was understandable in the light of parliamentary reactions to those whose speeches threatened to tow the Houses into the waters of theological controversy and church history. The conduct of such members was plainly unacceptable and they were roundly rebuked for wasting parliamentary time.

What has been demonstrated so far is the clear impact of the parliamentary context and secular law reform agenda upon ecclesiastical reforms. It was equally clear, however, that ecclesiastical reforms could potentially affect secular court reform in Parliament. Both Selborne and Cairns originally opposed the inclusion of ecclesiastical appeals in the 1873 Bill precisely because they believed that the Bill would fail if it attempted to address the potentially divisive question of ecclesiastical appeals. Their first priority was to secure reform to the secular courts and they had do so with only limited parliamentary time, and in a manner acceptable to a diverse array of professional and political interests. While the 1873 Bill passed into law, at least one MP was convinced that the failure of the 1874 
Bill, which would have amended it was directly attributable to the excitement caused in Parliament by the Public Worship Regulation Act of that year.

\section{REFLECTIONS UPON THE COMPOSITION OF THE FINAL COURT OF ECCLESIASTICAL APPEAL UNDER THE 1873 AND 1876 ACTS}

Turning away from a consideration of the influence of the parliamentary context and process, a further, and related, area of interest concerns the substance of the reforms made in 1873 and 1876. This leads to a consideration of attitudes towards the role of the episcopal assessors, the relative merits of lawyers and bishops as judges, and perceptions of what it was that the court of final ecclesiastical appeal actually did.

As noted above, Lord Selborne's provision for episcopal assessors to assist the final court of ecclesiastical appeal mirrored provisions made in respect of colonial appeals, and also the concern that the new secular Court of Appeal should have access to specialist medical and other knowledge where that was appropriate. It was clear that he saw the episcopal assessors as a means of ensuring that the court had adequate access to ecclesiastical and theological expertise without compromising its legal character and composition. He hoped that this would meet the concerns of the opponents of the transfer of jurisdiction, who were concerned about lack of ecclesiastical expertise in the new court, and the concerns of those who objected to the mixed character of the Judicial Committee. In the years that followed, however, the provision for episcopal assessors was productive of more controversy than almost any other aspect of ecclesiastical jurisdiction.

The correspondence and trial notebooks of Archbishop Tait, Lord Cairns and Lord Selborne, demonstrated that the episcopal assessors played a strictly defined and limited role in respect of ecclesiastical appeals. Under the terms of the 1873 and 1876 Acts they were only consulted at the discretion of the court. After the hearing their role was simply to review the wording of the court's judgment to ensure that it did not have any unforeseen theological implications. Yet the common view, particularly amongst High Churchmen and the High Church press, was that the assessors played a dominant role in the formulation of the court's judgments.

Such views were foreshadowed in the debates of 1873 and 1876. In 1873 The Times likened Selborne's proposals to Bishop Blomfield's failed Bill of 1850, which would have referred all doctrinal suits to a panel of bishops for their opinion. It felt that that the real effect of the provision was to exclude legal influence in favour of a tyrannical spiritual influence. Similarly, in debates on the 1876 Act, the MP Beresford Hope, a High Churchman, argued that:

"The name and pretence of their being only 'assessors' would deceive no one. They were meant to be Judges, and only more influential Judges because not having countable votes they would exercise illicit influence. They would be to the real Court what a masterful wife was to her husband."

These assumptions about the role which the episcopal assessors played in ecclesiastical appeals raised questions relating to perceptions of the relative merits of bishops and lawyers as ecclesiastical judges. It was plainly important to those who sought the transfer of jurisdiction that the court should be staffed only by legally trained judges. By relegating the bishops to the role of assessors Selborne sought to achieve this, but why was it so important? An answer to this question was found in the contrasting characterisation of lawyers and bishops. Lord Salisbury, for example, enunciated a widely held opinion when he told the House of Lords in 1873 that:

"He did not desire to throw the shadow of a reflection on the

Members of the Episcopal Bench... but if they were impartial it was a special merit, Bishops being the least likely persons to carry impartiality into questions deeply interesting them.

They were likely to have pledged themselves at some period of their career to one side or the other; they had probably expressed opinions more or less strong on particular subjects, and they had none of that freedom from interest or prejudice which we are proud to recognise in the Judges of the land.

They could not in the nature of the case be the most impartial tribunal, and they certainly were not educated for law."

In contrast to a portrayal of bishops as incompetent to decide matters of law, and subject to bias, lawyers were portrayed as paragons of impartiality and reason. As Dr Ball MP (a lawyer) put it:

"[A] thoroughly practiced lawyer had no feeling at all, any more than he had about problems he was working out."

On one level assumptions about the character and capabilities of bishops could be explained as a reflection of the social, political and religious context of those who enunciated them. They reflected common beliefs regarding both the detrimental effect of religious enthusiasm upon reason and intellect, and the skills and abilities of the clergy. In a sense, too, the bishops were experiencing the consequences of attempts both to professionalise the clergy, and to enhance their identity as distinct from the laity and possessed of special qualities. On another level, attitudes towards the bishops reflected assumptions about what it was that the court of final ecclesiastical appeal should be doing. The general tenor of the debates was that a court in which the bishops played a significant role was doing something more than just law. This, it was argued, was improper. In a court which should have been deciding law it was improper and inexpedient to have episcopal judges, who were neither trained nor fitted to the task.

The next question was why it was so important to the supporters of the Hardy's amendment that the court of final ecclesiastical appeal should be seen as doing only law. One answer was that both the new Court of Appeal and the 
Judicial Committee had received ecclesiastical jurisdiction by virtue of an Act of Parliament. At a time when certain elements within the Church were asserting its authority, autonomy, and identity as a spiritual body it was potentially disastrous for a court constituted under statute to appear to decide the theology or ecclesiastical policy of the Church. Indeed the Judicial Committee had always been careful to emphasise that what it decided was the law, and not the soundness or orthodoxy of any particular doctrine.

Another, related, explanation was that, at a time when the Church was increasingly divided by theological differences and controversies, the law applied by a court staffed by lawyers was widely viewed as the only possible hope of maintaining a doctrinally broad and comprehensive Church which was capable of fulfilling a national mission. The Church's formularies had established a legal ring-fence within which a range of doctrinal positions were acceptable. This was endangered by the role of ecclesiastics in ecclesiastical appeals since their natural tendency was to propound their own theological views as the truth, and to persecute those who differed from them.

Even if they could be trusted not to engage in doctrinal witch-hunts, and even if some theological expertise was required, their opponents argued that the bishops were not qualified to act as either judges or assessors. Not only did they lack legal training or attributes, but there was no guarantee that they were learned in theology or representative of the Church. Neither of these qualities were, their detractors argued, significant in the decisionmaking processes of those who appointed them.

Despite these explanations there remained one conundrum to be resolved, namely, why in 1873 and 1876 High Churchmen in particular supported the transfer of ecclesiastical appeals to a court staffed exclusively by lawyers; and why many of them opposed the role of episcopal assessors. This was, after all, a volte face in respect of previous High Church reform initiatives, all of which would have strengthened the ecclesiastical element of the final court to the detriment of the legal element. Moreover, by the time the Royal Commission of Ecclesiastical Courts took evidence in 1883 it was apparent that many High Churchmen had lost their faith in lawyers and were once again advocating a final court of appeal staffed only by ecclesiastics.

The conduct of High Church supporters of the reform were equally puzzling when considered in light of their usual attitudes towards Church questions and reform. They had previously lambasted the Judicial Committee for its failure to condemn heterodox doctrine, indicating that they had little sympathy with its role in the legal protection of a range of doctrinal positions. Further, of all sections within the Church they probably had the most advanced confessions for the Church as a confessional body defined by reference to strict standards. As such, they had, at first glance, little cause to be sympathetic to the idea that legally trained judges would maintain the breadth of the Church and thus ensure that it was fitted to its role as a national and Established body.

One possible explanation for High Church support for a purely legal court was their antipathy towards the current occupiers of the episcopal bench. The practices of the more extreme element of the High Church had found little favour with the bishops of the time and relationships were often strained. Another explanation was that by 1873 the ecclesiastical appeals being heard by the Judicial Committee were almost entirely concerned with High Church practices and the extreme High Church was dissatisfied with its treatment at the hands of the mixed Judicial Committee. Given this, and given the opposition of the bishops, perhaps they decided that they were better off with a court of appeal which would concern itself only with questions of law. In effect, they would trust to lawyers to maintain the legal ring-fence of the formularies which would, it was hoped, safeguard their practices and protect them from ecclesiastical persecution.

Several prominent people, including Archbishop Tait, advanced another reason, arguing that the proposed transfer of jurisdiction to the new Court of Appeal was part of a High Church conspiracy. Some conspiracy theorists contended that the reason Selborne's amendment was supported was that it would secure what Blomfield had wanted, namely reference of all doctrinal suits to a panel of bishops for their opinion, which would in effect bind the hands of the court. Given the High Church's distrust of the bishops this was unlikely.

However, other conspiracy theorists argued that what the High Church wanted was to secure the transfer of ecclesiastical jurisdiction to a court which, since it was created by Parliament without reference to Convocations, and since (in the original conception) it had no ecclesiastical personnel, would lack the spiritual authority which the High Church deemed necessary to bind their consciences in spiritual matters. In other words they sought a justification for disobedience to the judgments of the final court of ecclesiastical appeal. Given the future conduct of High Church defendants, this was an entirely plausible explanation of their role in the passage of the 1873 and 1876 Acts.

\section{CONCLUSION}

Our history of ecclesiastical appeals and their place in the history of the reforms introduced by the Judicature Act 1873 has ended with allegations of skulduggery and intrigue. It is hoped, however, that it has served to illustrate two things. Firstly, it demonstrates the significance of the parliamentary context and process in shaping attempts to reform ecclesiastical jurisdiction. This context fundamentally affected the arguments advanced, and created a nexus between ecclesiastical and secular 
court reform which had a profound impact upon the reforms advanced. The fact that ecclesiastical and secular law reform intersected in Parliament also meant that the fate of secular reforms could be affected by ecclesiastical controversies. Secondly, though, this history shows that proposals for ecclesiastical court reform were strongly influenced by the religious sympathies and assumptions of the protagonists. It is upon this aspect of the history of ecclesiastical appeals that attention is most often focussed; but it is hoped that this article has demonstrated that it cannot be fully understood without reference to the legal and political context in which reforms took place.

\section{Dr Charlotte Smith}

Lecturer, Co-Director of the Forum for Legal and Historical Research, School of Law, University of Reading 